\title{
Pembingkaian media mengenai "Sudut Dilan" yang terinspirasi Film Dilan 1990 dan 1991
}

\author{
Aceng Abdullah ${ }^{1}$, Rangga Saptya Mohamad Permana ${ }^{2}$ \\ ${ }^{1,2}$ Universitas Padjadjaran, Bandung, Indonesia
}

\begin{abstract}
ABSTRAK
Dilan 1990 dan Dilan 1991 merupakan film Indonesia yang terbilang sukses dari segi juumlah penonton. Kesuksesan kedua film tersebut memicu sebuah pemberitaan tentang rencana pembangunan "Sudut Dilan" di Bandung oleh Gubernur Jawa Barat (Jabar) Ridwan Kamil yang disorot tajam oleh banyak media dan masyarakat Bandung bahkan secara nasional. Dua media yang kerap memproduksi pemberitaan tersebut adalah HU Pikiran Rakyat dan Tribun Jabar. Penelitian ini bertujuan untuk mengetahui framing pemberitaan menganai pembangunan "Sudut Dilan" pada HU Pikiran Rakyat dan Tribun Jabar. Data-data dianalisis menggunakan teknik analisis framing Robert M. Entman, framing dibagi menjadi dua dimensi, yakni dimensi seleksi isu dan dimensi penonjolan aspek-aspek tertentu dari pemberitaan "Sudut Dilan" dalam HU Pikiran Rakyat dan Tribun Jabar. Hasil penelitian menunjukkan bahwa: (1) Pikiran Rakyat mendefinisikan masalah ini sebagai sebuah "agenda seorang politikus lima tahun ke depan", sedangkan Tribun Jabar mendefinisikan masalah pembangunan "Sudut Dilan" ini sebagai masalah Pariwisata; (2) Penyebab dari polemik yang muncul, menurut Pikiran Rakyat disebabkan oleh tidak adanya kejelasan urgensi yang logis mengapa taman atau sudut di Lapangan Saparua itu harus dibangun dan dinamai Sudut Dilan, dan hal yang sama ditulis oleh Tribun Jabar; dan (3) Untuk penyelesaian masalah, karena warga Jawa Barat pada umumnya menolak nama Dilan, maka baik itu menurut Pikiran Rakyat maupun Tribun Jabar, gagasan Gubernur Jawa Barat yang akan membangun Taman atau Sudut Dilan itu sebaiknya dibatalkan, atau mengganti namanya dengan nama-nama tokoh Jawa Barat.
\end{abstract}

Kata-kata Kunci: Sudut Dilan; media; framing; pikiran rakyat; Tribun Jabar

$$
\begin{gathered}
\text { Media framing about "Sudut Dilan" } \\
\text { which inspired by Dilan } 1990 \text { and } 1991 \text { Films }
\end{gathered}
$$

\begin{abstract}
Dilan 1990 and Dilan 1991 are fairly successful Indonesian films, in terms of the number of spectators. The success of the two films triggered a story about the development plan of a corner named Dilan or "Sudut Dilan" in Bandung by the Governor of West Java, Ridwan Kamil, which was sharply highlighted by many media. The two media that often produce the news are Pikiran Rakyat and Tribun Jabar newspapers. This study aims to determine news framing about the construction of the "Sudut Dilan" in Pikiran Rakyat and Tribun Jabar newspapers. The data were analyzed using the Robert M. Entman framing analysis technique, which framing is divided into two dimensions, namely the dimension of issue selection and emphasizing certain topic. The results show that: (1) Pikiran Rakyat defines this problem as an "agenda of a politician for the next five years", while Tribun Jabar defines it as a matter of tourism; (2) According to Pikiran Rakyat and Tribun Jabar, this issue arises due to the lack of clear logical urgency why the park or corner in Saparua Square must be built and named "Sudut Dilan"; and (3) For solving the problem, Pikiran Rakyat and Tribun Jabar suggest that the plan of West Java Governor, who will build the park or Sudut Dilan should be canceled, or replace the name with the names of West Java figures.
\end{abstract}

Keywords: Sudut Dilan; media; framing; Pikiran Rakyat; Tribun Jabar

Korespondensi: Dr. Aceng Abdullah, M.Si.. Program Studi Televisi dan Film, Fakultas Ilmu Komunikasi, Universitas Padjadjaran. Jalan Raya Bandung-Sumedang KM. 21 Jatinangor 45363. Email: aceng.abdullah@ unpad.ac.id. 


\section{PENDAHULUAN}

Dilan 1990 dan Dilan 1991 merupakan film Indonesia yang terbilang sukses. Film remaja ini menceriterakan tentang kisah cinta anak sebuah SMA di Bandung, yakni Milea (diperankan oleh Vanessa Priscillia) dan Dilan (diperankan oleh Iqbaal Ramadhan). Cerita ini ditulis oleh penulis Pidi Baiq dengan setting kota Bandung tahun 90-an. Romantika kisah asmara dua remaja ini menjadi setting utama film ini. Gejolak kaum muda pun ditunjukan dengan adegan tawuran antar geng, bahkan ada adegan kekerasan terhadap guru di sekolah oleh tokoh Dilan. Film ini disutradarai oleh Fajar Bustomi dan Pidi Baiq sekaligus penulis naskah film ini.

Film Dilan 1990 berhasil meraup jumlah penonton hingga 6,3 juta penonton. Dengan jumlah penonton sebanyak itu, film Dilan 1990 menjadi film paling banyak penontonnya selama tahun 2018. Peringkat keduanya pun jumlah penontonnya hampir setengah dari Dilan 1990. Jumlah penonton Dilan 1990 pun terbilang spektakuler dalam sepuluh tahun terakhir. Film ini juga menjadi film peringkat kedua paling banyak penontonnya setelah Warkop DKI Reborn (Jangkrik Boss!) yang ditonton oleh sekitar 6,8 juta penonton ("Film Indonesia," n.d., 2019).

Sukses dengan film pertama, produser memanfaatkan momen tersebut dengan memproduksi film kedua yakni Dilan 1991. Film kedua ini mampu meraih posisi puncak film Indonesia terbanyak penontonnya pada tahun 2019 kendati angkanya masih di bawah Dilan 1990, yakni mencapai 5,2 juta penonton. Sekuel Dilan ini menjadi film peringkat ke-2 dan ke-3 sebagai film Indonesia yang paling banyak penontonnya dalam 10 tahun terakhir ini. Untuk lebih detilnya dapat dilihat pada tabel 1 .

Dari data tersebut terlihat dalam 10 tahun terakhir ini Film Dilan 1990 dan Dilan 1991 menjadi tiga besar film Indonesia yang paling banyak ditonton di bioskop di seluruh Tanah Air, bahkan Dilan 1990 angka penontonnya (6,3 juta) hampir mendekati film Warkop DKI

Tabel 1 Peringkat 10 Film Indonesia Dengan Jumlah Penonton Terbanyak Tahun 2008-2019

\begin{tabular}{clcc}
\hline No & \multicolumn{1}{c}{ Judul Film } & Penonton & Tahun \\
\hline 1 & Warkop DKI Reborn: & 6.858 .616 & 2016 \\
& Jangkrik Boss! part 1 & & \\
2 & Dilan 1990 & 6.315 .664 & 2018 \\
3 & Dilan 1991 & 5.253 .411 & 2019 \\
4 & Laskar Pelangi & 4.719 .453 & 2008 \\
5 & Habibie \& Ainun & 4.583 .641 & 2012 \\
6 & Pengabdi Setan & 4.206 .103 & 2017 \\
7 & Warkop DKI Reborn: & 4.083 .190 & 2017 \\
& Jangkrik Boss Part 2 & & \\
8 & Ayat-ayat Cinta & 3.676 .210 & 2008 \\
9 & Ada Apa Dengan Cinta & 3.665 .509 & 2016 \\
& 2 & & \\
10 & Suzzanna: Bernapas & 3.346 .185 & 2018 \\
& dalam Kubur & & \\
\hline
\end{tabular}

Sumber: Film Indonesia, n.d, 2019 
Reborn: Jangkrik Boss Part 1. Bahkan film legendaris Ayat Ayat Cinta, Ada Apa Dengan Cinta, Habibie \& Ainun, serta Laskar Pelangi yang sebelumnya disebut-sebut sebagai film Indonesia spektakuler karena jumlah penontonnya berada di atas 3 juta, ternyata terlampaui oleh sekuel Dilan ini.

Tingginya jumlah penonton film Dilan 1990 dan Dilan 1991 tersebut tentu saja menjadi bahan pemberitaan media massa. Salah satunya adalah pemberitaan tentang rencana pembangunan "Taman Dilan" di Bandung oleh Gubernur Jawa Barat (Jabar) Ridwan Kamil. Pemberitaan tersebut banyak mendapat perhatian media dan masyarakat Bandung bahkan secara nasional. Jika sebuah isu menjadi masif, media acapkali dianggap sebagai institusi/agen penting diplomasi publik yang mempromosikan kepentingan nasional di arena internasional (Rawan, Hussain, \& Khurshid, 2018).

Melihat tingginya jumlah penonton dua film Dilan 1990 dan Dilan 1991 ini diyakini Gubernur Jabar Ridwan Kamil akan berpengaruh terhadap kunjungan wisatawan ke kota Bandung karena diharapkan para penonton penasaran tempattempat yang dijadikan lokasi syuting akan didatangi wisatawan. Mungkin Ridwan Kamil melihat kesuksesan lokasi syuting Laskar Pelangi di Kep. Bangka Belitung. Film Laskar Pelangi ini pada tahun 2008 ditonton oleh 4,7 juta penonton dan hingga kini lokasi syutingnya menjadi tujuan wisata daerah tersebut.

Ketika film Dilan 1990 dan Dilan 1991 berhasil menarik jumlah penonton yang besar, Ridwan Kamil juga berniat membuat satu taman di kawasan Gelora Jalan Saparua dengan nama Taman Dilan. Selain jumlah penonton, pengaruh film juga amat besar terhadap jiwa manusia dalam waktu yang lama, terutama bagi remaja (Sadono, 2015). Namun pembangunan taman ini gagal dilakukan karena banyaknya kritik dari masyarakat, baik melalui media sosial maupun media massa. Pembangunan taman pun dibatalkan dan diganti dengan sebuah titik di kawasan Gelora Saparua dengan nama "Sudut Dilan". Tujuannya sama, yakni sebagai salah satu daya tarik wisata bagi kota Bandung. Itu sebabnya tatkala peletakan batu-pertamanya hadir pula Menteri Pariwisata Indonesia saat itu, yakni Arief Yahya.

Kendati Taman Dilan sudah berganti nama menjadi Sudut Dilan namun polemik tentang pembangunannya masih muncul baik melalui media sosial maupun media massa. Harian Umum Pikiran Rakyat (PR) sebagai surat kabar terbesar dan tertua di Jawa Barat memberikan porsi yang lumayan besar terhadap rencana pembangunan Sudut Dilan. Begitu pula Tribun Jabar, koran harian dengan oplah yang hampir menyamai "PR" juga ikut memberitakan. Tribun Jabar adalah surat kabar harian yang 
terbit pasca-reformasi dan merupakan grup penerbitan Kompas Gramedia Grup.

Dua surat kabar ini dipilih untuk dianalisis pemberitaan dengan pertimbangan sebagai berikut. Pertama, Pikiran Rakyat dan Tribun Jabar merupakan media massa yang terbit di Bandung dan keduanya memberitakan masalah yang terjadi di kota Bandung ini. Kedua, media tersebut merupakan media massa besar yang memiliki kredibilitas dalam keredaksiannya sehingga keduanya memiliki tiras yang besar bahkan Tribun Jabar pada beberapa tahun lalu tirasnya pernah melampui tiras Pikiran Rakyat. Ketiga, pengamatan awal terhadap pemberitaan tentang Sudut Dilan ini keduanya memiliki perspektif yang berbeda akan masalah yang ada.

Ihwal perbedaan pemberitaan menjadi sebuah realitas dalam dunia jurnalistik. Kendati sebuah karya jurnalistik harus mengacu kepada prinsip-prinsip jurnalistik yakni prinsip faktualitas, obyektivitas, aktualitas, netralitas dan mengedepankan etika media, namun dalam kenyataannya perspektif atau arah pemberitaannya tidak selalu serupa bahakan perspektifnya bisa saling berseberangan antara media yang satu dengan media yang lain. Hal ini tidak hanya terjadi di Indonesia tetapi juga di negara-negara maju.

Media massa dalam pemberitaannya seringkali melakukan pembingkaian sebuah peristiwa. Fakta yang ditampilkan dalam media diproduksi sedemikain rupa sehingga berita antara satu media dengan media lainnya menjadi berbeda. Sebuah peristiwa oleh media yang satu bisa dibingkai dengan indah, tetapi sebaliknya oleh media yang yang lain dapat dibingkai dengan buruk. Itulah framing media. Konsep framing dan analisis bingkai berasal dari karya Erving Goffman (1974) dan Gregory Bateson (1972). Mereka masing-masing secara mandiri mengembangkan konsep kerangka sebagai "skema penafsiran" yang memungkinkan khalayak untuk "menemukan, memahami, mengidentifikasi, dan memberi label" fenomena sosial (McDonald, 2019).

Framing ini pun terjadi di hampir seluruh belahan dunia karena konten media massa massa dipengaruhi oleh berbagai hal sehingga pemberitaannya menjadi berbeda antara media yang satu dengan media lainnya. Shoemaker \& Reese memaparkan teori yang mempengaruhi isi media. Menurutnya, isi media sedikitnya dipengaruhi lima hal, yakni 1) Individu dalam media, 2) Rutinitas media, 3) Organisasi media, 4) Institusi Media dan 5) Sistem sosial (Shoemaker \& Reese, 1996).

Individu dipengaruhi oleh rutinitas media atau juga kebiasaan media. Rutinitas media juga dipengaruhi oleh organisasi media, organisasi media ini dipengaruhi pula institusi media, dan institusi media dipengaruhi oleh sistem sosial di mana media tersebut berdiri, dan pada akhirnya, 
media dapat memengaruhi opini dan sikap masyarakat (mediatisasi) (Nugroho, 2019). Semuanya itu dikenal sebagai teori Hirarki Pengaruh dimana lingkaran terdalam (individu) dipengaruhi oleh komponen-komponen lainnya.

Setiap media massa memiliki kebijakan dan arah keredaksian yang berbeda dengan media lainnya. Ketika menghadapi sebuah peristiwa atau fenomena, media selalu melakukan pencarian isu, memilah isu, lalu memilih isu. Dari isu terpilih kemudian dilakukan pengolahan isu dengan cara menambah atau mengurangi fakta di lapangan sesuai dengan maksud dan tujuan media tersebut. Fakta bisa dilengkapi dengan cara melakukan reportase tambahan, baik itu dengan cara wawancara dengan narasumber tambahan, observasi lapangan maupun penggalian referensi yang berkaitan dengan peristiwa atau fenomena yang terjadi. Secara singkat, teori Hirarki Pengaruh ini menjelaskan tentang pengaruh terhadap isi dari suatu pemberitaan media oleh pengaruh internal dan eksternal (Maulana \& Fatmawati, 2018).

Sejumlah komponen teori Hirarki Pengaruh membawa sebuah media untuk melakukan pembingkaian terhadap sebuah peristiwa. Misalnya ketika mengulas sebuah peristiwa bagaimana media tersebut mengartikan sebuah fakta sebagai perstiwa atau kejadian tertentu. Apakah itu sebagai peristiwa politik, ekonomi, sosial, budaya atau sebagai peristiwa lainnya. Selain itu, media juga biasa melakukan perkiraan atau penyebab masalah, sehingga jika terjadi sebuah peristiwa, peristiwa tersebut akan menyebutkan hal itu karena disebabkan oleh faktor X sedangkan media yang lain bisa menyebutkan sebagai faktor $\mathrm{Y}$ begitupun, media lainnya juga bisa memaparkan sebagai faktor Z. Hal ini terlihat dalam hasil penelitian yang dipublikasikan oleh Bawazier \& Nurhajati (2018), di mana disebutkan bahwa swafoto yang dilakukan oleh Miss Israel dan Miss Lebanon menuai kontroversi di dunia internasional dan menjadi viral; hal tersebut dibingkai secara "rapi" oleh 2 media besar dunia, yakni CNN dan BBC (Bawazier \& Nurhajati, 2018).

Selain hal tersebut, media juga acapkali menggunakan nilai moral tertentu untuk menjelaskan masalah dari sebuah peristiwa yang terjadi. Nilai moral apa yang dipakai untuk meligitimasi atau mendelegitimasi pada sebuah kejadian atau peristiwa. Begitupun tatkala melontarkan penyelesaian masalah, antara satu media dengan media lainnya akan memiliki perbedaan. Berdasarkan hal tersebut, untuk mengetahui semua itu, penulis akan menganalisis konten berita tentang pemberitaan Sudut Dilan yang dimuat oleh Harian Umum (HU) Pikiran Rakyat ("PR") dan Harian Tribun Jabar dengan perspektif pembingkaian (framing) dari Robert M. Entman. 


\section{METODE PENELITIAN}

Para peneliti media, khususnya dalan menganalisis berita yang dimuat atau disiarkan oleh media massa, sudah sangat akrab dengan framing dari Robert M. Entman. Biasanya metode analisis framing dari Entman ini digunakan untuk berita-berita kasus yang dimunculkan oleh media. Dalam wacana yang kritis seperti konflik, media tidak hanya melakukan peran komunikator risiko informal, tetapi juga menjadi arena utama di mana definisi sosial, konstruksi dan konsekuensi risiko dapat dieksplorasi (Jemison, 2017). Framing sendiri merupakan salah satu pendekatan penelitian yang berpusat pada khalayak yang berkembang pada era 1980-an di Amerika Serikat dan berakar pada interaksi simbolik dan konstruksi sosial.

Konsep framing digunakan untuk menggambarkan proses seleksidan menonjolkan aspek tertentu dari realitas oleh media. Framing dapat dipandang sebagai penempatan berbagai fakta atau opini dalam konteks yang khas sehingga isu tertentu mendapatkan alokasi lebih besar daripada isu yang lain, atau bahkan menghilangkan isu tertentu tetapi melebihkan isu yang lain. Framing pun memberikan tekanan lebih pada bagaimana teks komunikasi ditampilkan dan bagian mana yang ditonjolkan atau dianggap penting oleh pembuat teks
(Eriyanto, 2002).

Bentuk penonjolan tersebut bisa beragam. Menempatkan aspek informasi lebih menonjol dibandingkan yang lain, lebih mencolok, melakukan pengulangan informasi yang dipandang penting atau dibungkam dengan aspek budaya yang akrab di benak khalayak. Dengan bentuk seperti itu, sebuah ide atau informasi lebih mudah terlihat, lebih mudah diperhatikan, diingat dan ditafsirkan karena berhubungan dengan skema pandangan khalayak. Karena kemenonjolan adalah produk interaksi antara teks dan penerima, kehadiran frame dalam teks bisa jadi tidak seperti yang dideteksi oleh peneliti, khalayak sangat mungkin mempunyai pandangan apa yang dia pikirkan atas suatu teks dan bagaimana teks berita tersebut dikonstruksi dalam pikiran khalayak (Eriyanto, 2002).

Framing tidak hanya dapat memengaruhi pikiran khalayak sehingga bisa menimbulkan opini publik, tetapi mungkin yang lebih penting memengaruhi mereka yang membuat keputusan kebijakan. Itu juga memengaruhi sistem media (misalnya wartawan, editor, organisasi media, anggota dewan, dan opinion leader); yang kerangka dan persepsi individualnya tidak terlepas dari, atau terisolasi dari, efek komunikasi massa yang lebih luas. Media memainkan peran kunci melalui kegiatan frame building (teknik penonjolan narasi) dan frame setting (teknik mengkomunikasikan bingkai) 
(McLennan, Becken, \& Moyle, 2017).

Robert M. Entman melihat framing dalam dua dimensi besar, yakni seleksi isu dan penekanan atau penonjolan aspek-aspek tertentu dari realitas. Penonjolan, merupakan sebuah proses dimana informasi menjadi lebih bermakna, lebih menarik, berarti, atau lebih diingat oleh khalayak. Dalam praktiknya, framing dijalankan oleh media dengan menyeleksi isu tertentu dan mengabaikan isu yang lain; dan menonjolkan aspek dari isu tersebut dengan menggunakan berbagai strategi wacana yakni penempatan yang mencolok, pengulangan, pemakaian grafis yang mendukung dan memperkuat penonjolan, pemakaian label tertentu ketika menggambarkan orang yang diberitakan, asosiasi terhadap simbol budaya, generalisasi, simplifikasi. Cara pandang atau perspektif itu pada akhirnya menentukan fakta apa yang diambil, bagian mana yang ditonjolkan dan dihilangkan.

Aspek Seleksi Isu ini berhubungan dengan pemilihan fakta. Dari realitas yang kompleks dan beragam itu, aspek mana yang diseleksi untuk ditampilkan? Dalam proses seleksi isu ini selalu di dalamnya terkandung bagian berita yang dimasukan (included), tetapi ada juga berita yang dikeluarkan (excluded). Tidak semua aspek atau bagian dari isu ditampilkan, wartawan memilih aspek tertentu dari suatu isu.

Sedangkan pada penonjolan aspek tertentu, Aspek ini berhubungan dengan penulisan fakta.
Ketika aspek tertentu dari suatu peristiwa tersebut telah dipilih, bagaimana aspek tersebut ditulis? Hal ini sangat berkaitan dengan pemakaian kata, kalimat, gambar, dan citra tertentu untuk ditampilkan kepada khalayak. Berdasarkan semua hal tadi, Entman membagi pembahasan pembingkaian berita oleh sebuah media menjadi empat aspek pokok yang kemudian bisa dijadikan sebagai unsur untuk dianalisis, yakni:

Define problems (Pendefinisian masalah). Bagaimana suatu peristiwa atau isu dipandang oleh sebuah media? atau sebagai masalah apa? Boleh jadi, antara satu media dengan media lainnya bakal memiliki pandangan yang berbeda, perbedaan pendefinisian masalah yang muncul. Ketika banjir besar melanda sebuah kota, sebuah media akan mendefinikan bahwa hal tersebut sebagai masalah bencana alam, media lainnya mendefinisikannya sebagai masalah lingkungan, tapi ada pula yang mendefiniskan hal tersebut merupakan sebagai masalah rendahnya kualitas SDM pemerintahan, kegagalan birokrasi bahkan boleh jadi merupakan masalah politik.

Diagnose causes (Perkiraan Penyebab Masalah). Media pun akan menulis sebuah peristiwa yang diangkat menjadi berita itu disebabkan oleh apa? Apa penyebab dari munculnya suatu masalah? Siapa pelaku utama yang dianggap sebagai penyebab masalah? 
Aneka dugaan ini dapat muncul dari hasil wawancara narasumber yang juga dipilih oleh media tersebut sesuai dengan framing yang sudah direncanakan. Hasil wawancara ini pun diseleksi dan hanya pernyataan-pernyataan yang mendukung framing media tersebut yang dikutip dan ditulis menjadi sebuah berita.

Make moral judgement (Pertimbangan moral). Sebuah media untuk meyakinkan kepada khalayaknya selalu memperkuat dengan berbagai hal yang berkaitan dengan nilai moral atau norma. Pertimbangan moral apa yang disajikan kepada khalayak untuk menjelaskan masalah? Hal-hal apa saja yang digunakan untuk meligitimasi atau mendelegitimasi sebuah tindakan.

Treatmentrecommendation(Rekomendasi). Media massa juga acapkali menawarkan rekomendasai untuk penyelesaian masalah dari suatu kasus. Penyelesaian masalah ini juga biasanya dimunculkan melalui fakta hasil wawancara dimana narasumbernya juga sudah dipilih oleh media sehingga arah penekanan penyelesaian masalahnya sejalan dengan framing media tersebut.

Berdasarkan paparan di atas, penelitian ini telah menganalisis pemberitaan tentang "Sudut Dilan" pada Harian Umum Pikiran Rakyat dan harian Tribun Jabar Bandung berdasarkan empat aspek di atas. Data-data dianalisis menggunakan teknik analisis framing Robert
M. Entman, di mana framing dibagi menjadi dua dimensi (Maulany \& Abdullah, 2019), yakni dimensi seleksi isu dan dimensi penonjolan aspek-aspek tertentu dari pemberitaan "Sudut Dilan" dalam HU "PR" dan Tribun Jabar, di mana dari masing-masing surat kabar tersebut dipilih 6 berita $(P R)$ dan 7 berita (Tribun Jabar) sebagai unit analisis.

\section{HASIL DAN PEMBAHASAN}

Pemberitaan tentang film Dilan di kedua media massa yang diteliti ini cukup banyak; di "PR" ditemukan 15 berita dan di Tribun Jabar ada 31 berita. Namun berita yang berkaitan dengan pembangunan "Taman Dilan" atau Sudut Dilan masing-masing pada " $P R$ " tercatat 6 berita dan Tribun Jabar ada 7 Berita.

Selain berbentuk berita, sebetulnya pada kedua media tersebut dimuat pula tajuk atau editorial yang membahas tentang Sudut Dilan ini, namun karena editorial bukan sebagai NEWS tetapi merupakan opini, maka editorial pada kedua media tersebut tidak kami analisis. Meskipun tidak menganalisisnya, namun editorial dari media yang diteliti dijadikan rujukan, mengingat editorial merupakan sikap dan pendapat dari sebuah media terhadap suatu masalah. Perspektif pemberitaan pun tidak terlepas dari sikap media terhadap suatu masalah yang terjadi di masyarakat. Berikut ini tabel judul berita dan tanggal pemuatan di 


\begin{tabular}{|c|c|c|c|}
\hline \multirow[t]{2}{*}{ bel } & \multicolumn{2}{|c|}{$\begin{array}{l}\text { Berita yang } \\
\text { Pembangunan }\end{array}$} & \multirow{2}{*}{$\begin{array}{r}\text { Berkaitan } \\
\text { Sudut } \\
\text { Rakyat }\end{array}$} \\
\hline & Dilan Pada & Pikiran & \\
\hline $\mathrm{No}$ & Judul Berita & \multicolumn{2}{|c|}{ Edisi } \\
\hline 1 & $\begin{array}{l}\text { Dongkrak Pariwisata, } \\
\text { Gubernur Ridwan Kamil } \\
\text { akan Bangun Taman Dilan }\end{array}$ & $\begin{array}{l}10 \\
2019\end{array}$ & Februari \\
\hline 2 & $\begin{array}{l}\text { Sudut Dilan di Kota } \\
\text { Bandung, Refleksi Upaya } \\
\text { Wisata Melalui Literasi } \\
\text { dan Film }\end{array}$ & $\begin{array}{l}24 \\
2019\end{array}$ & Feb \\
\hline 3 & $\begin{array}{l}\text { Nama Dilan di Ruang } \\
\text { Publik Berlebihan? Ini } \\
\text { Kata Para Pengamat }\end{array}$ & $\begin{array}{l}24 \\
2019\end{array}$ & Feb \\
\hline 4 & 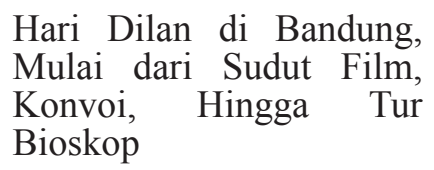 & 24 & $\mathrm{~F}$ \\
\hline 5 & $\begin{array}{l}\text { Ridwan Kamil dan } \\
\text { Arief Yahya Resmikan } \\
\text { Pembangunan Sudut Dilan } \\
\text { di Bandung }\end{array}$ & $\begin{array}{l}24 \\
2019\end{array}$ & Febr \\
\hline 6 & $\begin{array}{l}\text { Membincangkan } \\
\text { dan Sudut Dilan }\end{array}$ & $\begin{array}{l}25 \\
2019\end{array}$ & Februari \\
\hline 7 & $\begin{array}{l}\text { Ridwan Kamil Meradang } \\
\text { Ditanya Urgensi Bangun } \\
\text { Sudut Dilan }\end{array}$ & 26 & $\mathrm{Fe}$ \\
\hline 8 & $\begin{array}{lr}\text { Sudut Dilan Tak Ada } \\
\text { Urgensinya, } & \text { Hanya } \\
\text { Strategi Pemasaran Produk }\end{array}$ & $\begin{array}{l}27 \\
2019\end{array}$ & ebruari \\
\hline 9 & $\begin{array}{l}\text { Pojok Dilan atau Kabayan } \\
\text { dan Nyi Iteung? }\end{array}$ & 5 & et 2019 \\
\hline 10 & $\begin{array}{l}\text { Sudut Dilan Masuk } \\
\text { Revitalisasi GOR Saparua } \\
\text { Senilai Rp 5,9 miliar }\end{array}$ & 6 Mare & et 2019 \\
\hline
\end{tabular}

Sumber: Dokumentasi Penulis, 2019

kedua media tersebut, dapat dilihat pada tabel 2 .

Dari 10 (sepuluh) berita yang berkaitan dengan "Sudut Dilan" ini, penulis memilih 6 (enam) berita dari HU Pikiran Rakyat yang lebih relevan dan spesifik dalam pemilihan isu dan penekanan (penonjolan) masalah. Kelima berita itu adalah sebagai berikut, dapat dilihat pada tabel 3 .

Sedangkan untuk berita yang dimuat di Tribun Jabar, penulis memilih berita sebagai
Tabel 3 Berita HU Pikiran Rakyat yang Dianalisis

\begin{tabular}{|c|c|c|c|}
\hline No & Judul Berita & & disi \\
\hline 1 & $\begin{array}{l}\text { Dongkrak Pariwisata, } \\
\text { Gubernur Ridwan Kamil } \\
\text { akan Bangun Taman Dilan }\end{array}$ & $\begin{array}{l}10 \\
2019\end{array}$ & Februari \\
\hline 2 & $\begin{array}{l}\text { Nama Dilan di Ruang } \\
\text { Publik Berlebihan? Ini } \\
\text { Kata Para Pengamat }\end{array}$ & $\begin{array}{l}24 \\
2019\end{array}$ & Februari \\
\hline 3 & $\begin{array}{l}\text { Membincangkan } \\
\text { dan Sudut Dilan }\end{array}$ & $\begin{array}{l}25 \\
2019\end{array}$ & uari \\
\hline 4 & $\begin{array}{l}\text { Ridwan Kamil Meradang } \\
\text { Ditanya Urgensi Bangun } \\
\text { Sudut Dilan }\end{array}$ & $\begin{array}{l}26 \\
2019\end{array}$ & Februari \\
\hline 5 & $\begin{array}{lr}\text { Sudut Dilan Tak Ada } \\
\text { Urgensinya, } & \text { Hanya } \\
\text { Strategi Pemasaran Produk }\end{array}$ & $\begin{array}{l}27 \\
2019\end{array}$ & Februari \\
\hline 6 & $\begin{array}{l}\text { Pojok Dilan atau Kabayan } \\
\text { dan Nyi Iteung? }\end{array}$ & 5 & 2019 \\
\hline
\end{tabular}

Sumber: Dokumentasi Penulis, 2019

berikut, dapat dilihat pada tabel 4 .

Pembingkaian media (framing) oleh HU Pikiran Rakyat tentang peristiwa "Sudut Dilan" ditelaah menjadi empat bagian, yakni: (1) Pendefinisian Masalah (Define problems); (2) Perkiraan Penyebab Masalah (Diagnose causes); (3) Keputusan moral (Moral Judgement); dan (4) Penyelesaian Masalah (Treatment Recommendation). Berikut ini adalah pembahasan dan analisisnya.

Berdasarkan judul berita "Membincangkan Inggit dan Sudut Dilan” serta Nama Dilan di Ruang Publik Berlebihan? Yang dimuat Pikiran Rakyat, koran ini mendefinisikan masalah ini sebagai sebuah "Agenda Ridwan Kamil Lima Tahun ke Depan”, Kang Emil diperkirakan ingin membuat sebuah monumen yang terus diingat oleh generasi milenial untuk tujuan politik 
Tabel 4 Judul Berita yang Berkaitan dengan Pembangunan Sudut Dilan pada Tribun Jabar

\begin{tabular}{|c|c|c|c|}
\hline No & Judul Berita & & disi \\
\hline 1 & $\begin{array}{l}\text { Ini Lokasi untuk "Taman } \\
\text { Dilan" yang Dibangun } \\
\text { Ridwan Kamil, Akan Diisi } \\
\text { Mural dan Kata-kata Puitis }\end{array}$ & $\begin{array}{l}11 \\
2019\end{array}$ & Februari \\
\hline 2 & $\begin{array}{l}\text { Banyak yang Menolak } \\
\text { Taman Dilan, Mahasiswi } \\
\text { Ini Sebut Lebih Baik } \\
\text { Bangun Fly Over ke } \\
\text { Jatinangor }\end{array}$ & $\begin{array}{l}14 \\
2019\end{array}$ & Februari \\
\hline 3 & $\begin{array}{l}\text { Soal Rencana Ridwan } \\
\text { Kamil Bikin Taman Dilan, } \\
\text { Warga Ini Soroti Beberapa } \\
\text { Karakter Negatif Dilan }\end{array}$ & $\begin{array}{l}15 \\
2019\end{array}$ & Februari \\
\hline 4 & $\begin{array}{l}\text { Gubernur } \\
\text { Barat, Ridwan Kawa } \\
\text { Meresmikan Langsung } \\
\text { Sudut Film Dilan yang } \\
\text { Berada di Kawasan GOR } \\
\text { Saparua, Bandung }\end{array}$ & $\begin{array}{l}24 \\
2019\end{array}$ & Februari \\
\hline 5 & $\begin{array}{l}\text { Sambut Pemeran Dilan } \\
\text { dan Milea, Ridwan Kamil } \\
\text { Flashback Masa Pacaran: } \\
\text { Sama Seperti Zaman SMA } \\
\text { Saya }\end{array}$ & $\begin{array}{l}25 \\
2019\end{array}$ & Februari \\
\hline 6 & $\begin{array}{l}\text { Dilan dan Milea Kejutkan } \\
\text { Warga di Taman Saparua, } \\
\text { Sudut Dilan Diresmikan, } \\
\text { Jadi Ruang Literasi }\end{array}$ & $\begin{array}{l}27 \\
2019\end{array}$ & Februari \\
\hline 7 & $\begin{array}{l}\text { Rizal Ramli: Belum Lihat } \\
\text { Blueprint Ridwan Kamil } \\
\text { Kecuali Bikin Taman } \\
\text { Dilan }\end{array}$ & \multicolumn{2}{|c|}{13 Maret 2019} \\
\hline
\end{tabular}

Sumber: Dokumentasi Penulis, 2019

tertentu. Sebelum masuk ke masalah agenda politik, " $P R$ ” mengutip hasil wawancara dengan Prof. Dr. Asep Warlan, M.Si. yang menyatakan ketidak-relevanan rencana gubernur dalam membangun sebuah ruang publik berdasarkan tokoh fiktif dalam sebuah film.

Pengamat kebijakan publik dari Universitas Katolik Parahyangan Asep Warlan menilai penamaan "Dilan" di ruang publik tidaklah relevan. Asep mengatakan setiap kita membuat bangunan monumental pasti ada peristiwa kesejarahannya bagi masyarakat setempat.

"Ada simbol sosiologis dan makna yang terkandung dari bangunan monumental tersebut," ucapnya ketika dihubungi pada Minggu 24 Februari 2019.

Sementara bila profil "Dilan" yang dilekatkan dengan bangunan atau hal-hal yang monumental, dirasa tidak tepat bagi masyarakat Bandung. Asep tidak tahu apakah ini bagian dari upaya meraih simpati generasi milenial secara temporer ("Membincangkan Inggit dan Sudut Dilan,” 2019).

Pada berita tersebut, " $P R$ " sengaja memuat pernyataan dari narasumber Prof. Dr. Asep Warlan, M.Si. yang tidak setuju dengan pembangunan Sudut Dilan tersebut. Mengutip pernyataan Asep, Dilan ini, hanya tokoh fiktif yang diciptakan sebagai tokoh remaja dalam novel yang kemudian difilmkan. Dilan tidak memiliki makna khusus di Bandung. Ini hanya akan menjadi hal yang kontraproduktif. Memancing pro dan kontra dari masyarakat, Lebih lanjut Asep Warlan mengatakan tema bangunan atau ruang publik secara monumental harus ada kaitannya dengan ideologis dan perjuangannya. Asep menyebut masih banyak nama-nama yang lebih layak disematkan seperti Dewi Sartika dan Inggit Garnasih. Seperti yang tertuang dalam kutipan berikut ini:

"Saya merasa ini memang agak aneh. Tidak jelas konteksnya. Mungkin ada maksud 
politik, tapi rasanya tidak akan kapeunteun oleh masyarakat Bandung. Ini ruang publik, karena itu tokoh yang dilekatkan juga harus nama dan simbol yang berkaitan dengan ruang publik. Bukan hal yang sifatnya temporer," ("Membincangkan Inggit dan Sudut Dilan," 2019).

Selanjutnya, " $P R$ " mengutip hasil wawancara dengan seorang pakar politik, Dr. Firman Manan dari Fakultas Ilmu Sosial dan Politik Universitas Padjadjaran, dengan pemuatan berita sebagai berikut :

Sementara itu, pengamat politik Universitas Padjadjaran Firman Manan, penamaan ruang publik dengan tokoh fiktif "Dilan" ini akan memberikan insentif tersendiri bagi Ridwan Kamil. Sentimen positif akan lahir dari milenial, kata Firman, yang menilai bahwa Ridwan Kamil berhasil mempertahankan positioning dengan kedekatan milenial," ("Nama Dilan di Ruang Publik Berlebihan? Ini Kata Para Pengamat," 2019).

"PR" juga menurunkan berita berjudul

Ridwan Kamil Meradang Ditanya Urgensi Bangun Sudut Dilan, dalam edisi 26 Februari 2019 yang melakukan wawancara khusus dengan Wim Tohari Danieldi, dosen Universitas Pasundan Bandung. Berikut ini petikan wawancaranya:

Pengamat sosial dan akademisi Universitas Pasundan Wim Tohari Daniealdi tak habis pikir dengan kebijakan Ridwan Kamil menjadikan Dilan sebagai nama khusus sebuah sudut taman di area GOR Saparua Kota Bandung.

"Ini fenomena yang aneh, kalau sudah dibikin corner (Sudut Dilan), dari (tokoh) fiksi menjadi realitas, itu aneh, ini lebih parah lagi dimonumenkan," ucap Aldi saat dihubungivia telefon.

Menurut dia, monumen atau pelabelan suatu tempat dengan tokoh atau peristiwa tertentu merupakan upaya mengikat konteks agar generasi selanjutnya bisa mengingat atau mengambil hikmahnya. ("Ridwan Kamil Meradang Ditanya Urgensi Bangun Sudut Dilan," 2019).

Penyebab dari polemik yang muncul, bagi Pikiran Rakyat tidak adanya kejelasan urgensi yang logis mengapa Taman atau Sudut di Lapangan Saparua itu harus ada dan dinamai Sudut Dilan, sementara sosok Dilan sendiri dalamkisahfilmitubukanmerupakan sosok yang patut diteladani. " $P R$ ” pun lewat pernyataan salah seorang narasumbernya (budayawan Hawe Setiawan) mengatakan bahwa polemik ini merupakan strategi pemasaran dari produk film tersebut. Menurut Permana, dkk. (2019), kegiatan promosi film memang sama pentingnya dengan kegiatan produksi film itu sendiri. Hal tersebut dapat dilakukan dalam wujud seperti penayangan video klip original soundtrack (OST), penayangan teaser film, promosi melalui media konvensional/sosial, dan/atau pembagian merchandise film (Permana, Puspitasari, \& Indriani, 2019). Hal tersebut selaras dengan opini dari Setiawan (2019) berikut ini:

"Kegiatan Gubernur Ridwan Kamil, Wali Kota Oded M Danial, dan Menteri Pariwisata di Bandung yang antara lain berupa arak-arakan dan kumpul-kumpul terkait film Dilan 1991 hanyalah bagian dari sebagian remaja Kota di 
Bandung hari ini. Euforia itu tercipta antara lain dari strategi pemasaran produk industri pertunjukan," (Setiawan, 2019) via pesan WhatsApp kepada Pikiran Rakyat, Selasa 26 Februari 2019.

Apa yang dilakukan Ridwan Kamil dengan euforia Dilan memperlihatkan bertemunya pemasaran hiburan dan pemasaran politik. "Industri hiburan butuh penghebohan konsumen, politisi butuh branding yang melekat pada potensi pemilih dari kalangan milenial," |'“Sudut Dilan Tak Ada Urgensinya, Hanya Strategi Pemasaran Produk," 2019).

Pertimbangan moral dalam polemik penamaan Sudut Dilan ini menurut Pikiran Rakyat selain Dilan itu merupakan sosok fiktif, juga dalam sequel film tersebut tidak memberikan keteladanan yang baik. Sosok Dilan bukan sosok yang patut untuk diteladani sehingga khawatir dijadikan acuan oleh khalayak, seperti yang ditulis dalam berita berjudul Pojok Dilan atau Kabayan dan Nyi Iteung? ("PR" edisi 5 Maret 2019).

Asep Maung :Saya juga khawatir anakanak tidak bisa mencerna isi film tersebut secara gamblang karena ada adegan anakanak SMA yang ikut-ikutan geng motor. Asep Maung khawatir film berdampak terhadap perkembangan ahlak pelajar di Jawa Barat, khususnya siswa SMA yang cendrung sedang mencari jati diri.

"Kalau nanti ada taman atau Pojok Dilan, seolah-olah bahwa perilaku Dilan dan karakter Dilan itu harus dicontoh. Ini akan menjadi satu permasalahan moral tentunya," kata Asep Maung. ("Pojok Dilan atau Kabayan dan Nyi Iteung?," 2019).

Dalam upaya penyelesaian masalah, "PR" memunculkan berita berjudul Pojok Dilan atau Kabayan dan Nyi Iteung? (edisi 5 Maret 2019). Pada pemberitaan tersebut ditulis bahwa Pembangunan Sudut Dilan di Kota Bandung masih mengundang polemik. Warga Jawa Barat pada umumnya menolak rencana pembangunan yang digagas Gubernur Jawa Barat Ridwan Kamil. Oleh karena itu sebaiknya pembangunan Taman atau Sudut Dilan itu dibatalkan, atau mengganti nama dengan nama-nama tokoh Jawa Barat. " $P R$ " pun mewawancarai aktivis Lembaga Bantuan Pemantau Pendidikan Jawa

Barat, Asep Maung, Senin 4 Maret 2019.

"Rencana pembangunan taman dengan diberi nama Dilan ini membuat saya secara pribadi sangat kecewa. Warga Jabar lain pun banyak yang satu suara dengan saya. Mereka menilai rencana ini sangat berlebihan," kata pemerhati sosial dan pendidikan dari Lembaga Bantuan Pemantau Pendidikan Jawa Barat, Asep Maung, Senin 4 Maret 2019.

Asep Maung mengatakan, kalaupun Ridwan Kamil ingin memberikan apresiasi terhadap kesuksesan film Dilan, alangkah lebih baik penghargaan diberikan langsung kepada penulisnya, Pidi Baiq. Jika membangun taman dengan nama sesuai film, dia menilai hal itu sangat berlebihan. ("Pojok Dilan atau Kabayan dan Nyi Iteung?," 2019).

Dia menilai, berkaitan dengan literasi, akan lebih elok jika taman dinamai Taman Literasi. Atau bahkan lebih baik jika penamaan mengambil nama tokoh film di Jawa Barat. Kalau pun mau memberikan penghargaan 
kepada Pidi Baiq yang berhasil membuat sebuah

karya sastra yang filmnya ditonton oleh jutaan orang, berikan saja penghargaan langsung kepada penulisnya. Bahkan kalau mau lebih pas jika taman literasi itu diberi nama Kang Ibing, Kabayan atau Nyi Iteung yang identik dengan Jawa Barat, seperti dalam kutipan berita di bawah ini:

"Saya rasa ada yang lebih fenomenal dan lebih cendrung sesuai dengan karakter budaya yang ada di Jawa Barat, contohnya almarhum Kang Ibing dengan Kabayannya dan Nyi Iteungnya. Saya rasa nama Kabayan dan Iteung, orang se-Indonesia pun sudah tahu dan pasti identik dengan Jawa Barat. Kalau pun mau perorangan dengan mengedepankan nama dari pemeran, saya rasa almarhum Kang Ibing paling tepat," kata Asep Maung. ("Pojok Dilan atau Kabayan dan Nyi Iteung?," 2019).

Dengan masih adanya polemik Sudut Dilan di tengah masyarakat, Asep Maung meminta Ridwan Kamil mengkaji ulang pembangunan Sudut Dilan dan tidak memaksakan diri. Ia menambahkan:

Ridwan Kamil harus memikirkan aspirasi warga Jawa Barat dan jangan mengedepankan ide yang muncul dari inisiatif pribadi.

"Bukan artinya saya secara pribadi tidak menghargai, tapi justru ini karena perhatian saya ke gubernur. Hemat saya, pembuatan taman, patung, prasasti atau apapun itu, diharapkan identik dengan nilai-nilai budaya dan sejarah atau dengan namanama pejuang pendahulu kita yang ada di Jawa Barat ini. Jadi, jangan sampai jati teu kasilih ku junti," ujarnya. ("Pojok Dilan atau Kabayan dan Nyi Iteung?," 2019).
Lebih lanjut, pemberitaan tentang Dilan 1991 pada Harian Tribun Jabar secara kuantitatif dua kali lebih banyak ketimbang yang dimuat di HU Pikiran Rakyat. Pada Harian Tribun Jabar ditemukan 31 berita yang berkaitan dengan film Dilan '91, namun yang berhubungan dengan Taman Dilan atau Sudut Dilan terdapat sebanyak 7 berita. Berikut ini adalah pembahasan dan analisisnya.

Tribun Jabar mendefinisikan masalah pembangunan "Sudut Dilan" ini sebagai masalah Pariwisata. Sebagai film yang ditonton (di bioskop) oleh sekitar 6 juta orang ini diharapkan "Sudut Dilan" bakal mampu menyedot para wisatawan yang menonton film itu untuk datang ke Bandung. Namun, penamaannya yang kurang tepat karena sosok Dilan sendiri bukan sosok siswa yang patut diteladani.

Dalam berita Tribun Jabar berjudul Ini Lokasi untuk 'Taman Dilan” yang Dibangun Ridwan Kamil, Akan Diisi Mural dan Kata-kata Puitis, yang dimuat 11 Februari 2019 ditulis sebagai berikut:

Emil menjelaskan, Taman Dilan bukan sekadar urusan estetika. Namun, taman itu didedikasikan untuk film Dilan yang telah membuat Bandung semakin dikenal dan meningkatkan potensi pariwisatanya.

"Jadi visinya pariwisata. Kenapa wisatawan datang, ada yang lihat budayanya, 
arsitektur dan sebagainya. Jadi Taman Dilan itu didedikasikan pada cerita yang membuat Bandung luar biasa sebagai objek wisata. Jadi ini lebih pada pariwisata memanfaatkan budaya kontemporer," ucap Emil. (“'Ini Lokasi untuk ‘Taman Dilan' yang Dibangun Ridwan Kamil, Akan Diisi Mural dan Kata-kata Puitis,” 2019).

Dalam berita Tribun Jabar berjudul Soal Rencana Ridwan Kamil Bikin Taman Dilan, Warga Ini Soroti Beberapa Karakter Negatif Dilan, yang dimuat 15 Februari 2019 ditulis sebagai berikut:

Penolakan itu satu di antaranya datang dari Dewi (40), wanita warga Kota Bandung, saat ditemui Tribun Jabar di Taman Balai Kota Bandung, Jumat (15/2/2019). Dewi mengaku heran alasan Ridwan Kamil mengangkat nama Dilan sebagai nama taman padahal lebih bagus jika pakai nama pahlawan.

"Saya tidak setuju banget. Saya lihat sisi ini sebagai orang tua harus ditinjau lagi apa tujuan karakter Dilan," ujarnya. Dewi tidak melihat sisi positif dari pengangkatan karakter Dilan menjadi nama taman. Ia menyoroti beberapa karakter negatif Dilan di antaranya bolos sekolah, geng motor, naik motor tidak memakai helm, berantem, tawuran, dan emosional. ("Soal Rencana Ridwan Kamil Bikin Taman Dilan, Warga Ini Soroti Beberapa Karakter Negatif Dilan," 2019).

Tribun Jabar ingin menekankan, bahwa akar masalah dari polemik dan kritik tajam yang muncul tersebut karena sosok Dilan, siswa SMA sebagai tokoh utama film tersebut tidak memiliki karakter positif. Dilan adalah anggota geng motor, tukang berkelahi, bahykan pada cerutrera film tersebut ada penggambaran Dilan menghajar gurunya di sekolah.

Salah satu pertimbangan moral pembangunan Sudut Dilan ini, menurut Tribun Jabar adalah sisi positif berupa pojok literasi, seperti yang termuat pada berita berjudul Ridwan Kamil Resmikan Sudut Film Dilan di Kawasan GOR Saparua Bandung, pada edisi 24 Februari 2019.

"Hari ini kita mulai sebuah rencana Dilan Corner. Saya terima masukan dari Pak Menteri untuk sebutan Dilan Corner. Dilan Corner ini adalah ruang publik kecil di Taman Saparua ini untuk dijadikan taman literasi," kata Ridwan

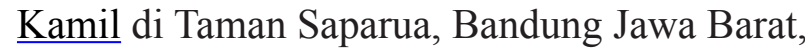
Minggu (24/2/2019).

"Jadi tempat ini nanti dipakai secara positif untuk membahas sastra, novel-novel dan mendiskusikannya, seperti inspirasi film Dilan dari novel untuk dikonversi menjadi film. Mudah-mudahan Dilan bisa mencapai kesuksesan literasi," terangnya. ("Gubernur Jawa Barat, Ridwan Kamil Meresmikan Langsung Sudut Film Dilan yang Berada di Kawasan GOR Saparua, Bandung,” 2019)

"Literasi Indonesia ranking 60 dari 65 negara, orang Indonesia malas baca buku, malas nulis, bagaimana mau jadi bangsa yang pandai kalau hoaks-nya banyak? Supaya menjadi bangsa yang mengapresiasi sastra, ruangannya selama ini kurang termanfaatkan, nah, kami bikin jadi positif," ujar Ridwan Kamil. ("Dilan dan Milea Kejutkan Warga di Taman Saparua, Sudut Dilan Diresmikan, Jadi Ruang Literasi,” 2019).

Bagi Ridwan Kamil, Sudut Dilan yang akan 
dibangun nantinya akan menjadi sudut literasi dimana orang bisa membahas karya-karya sastra, novel dan karya fiksi lainnya. Ridwan Kamil melihat sisi keluarbiasaan film ini yang bisa menggiring jutaan orang untuk menonton film dimana hal itu sesuatu hal yang luar biasa.

Solusi untuk penyelesaian masalah ini, Tribun Jabar memuat sebuah berita tentang penolakan warga melalui sebuah berita sekaligus di ujung berita memuat pernyataan seorang narasumber beritanya seperti tertulis dalam kutipan berita berjudul Banyak yang Menolak Taman Dilan, Mahasiswi Ini Sebut Lebih Baik Bangun Fly Over ke Jatinangor, yang dimuat pada tanggal 14 Februari 2019 di bawah ini:

Namun, rencana pembangunan "Taman Dilan" ini menuai kontroversi. Di media sosial justru banyak yang menolaknya. Satu di antaranya adalah Leony (20) seorang mahasiswi yang ditemui Tribun Jabar di Taman Lansia, Kota Bandung, Kamis (14/2/2019) siang. Menurut Leony, Ridwan Kamil terlalu berlebihan mengapresiasi Film Dilan, padahal masih banyak film lain yang layak diapresiasi.

Leony pun mengatakan, sebaiknya dana untuk membangun "Taman Dilan" dialihkan untuk membuat fasilitas lain yang lebih bermanfaat untuk masyarakat. "Lebih baik membangun Fly Over ke Jatinangor," kata Leony. Leony mengatakan "Taman Dilan" bisa saja menjadi daya tarik wisatawan untuk berkunjung ke Kota Bandung, namun masih banyak fasilitas lain yang perlu dibangun untuk menyejahterakan rakyat. ("Banyak yang Menolak Taman Dilan, Mahasiswi Ini Sebut Lebih Baik Bangun Fly Over ke Jatinangor," 2019).

Berdasarkan analisis hasil penelitian terhadap dua media di atas, sebetulnya ada satu hal yang belum dibahas oleh dua media tersebut. Pertama, Ridwan Kamil sebagai gubernur Jabar tampil pula dalam film tersebut memerankan salah seorang guru di sekolah Dilan dan Milea. Kedua, kelihatannya ada agenda tersendiri khususnya agenda politik dari Ridwan Kamil sendiri. Dengan dibangunnya Taman Dilan, hal itu menjadi sebuah monumen yang terus diingat dan didatangi oleh para wisatawan dari berbagai daerah di Indonesia sehingga diharapkan setiap orang yang datang khususnya generasi mileneal ke "Taman Dilan" akan langsung ingat Ridwan Kamil.

Ridwan Kamil merupakan salah satu pejabat publik yang dekat dengan kaum Milenial, hal ini karena yang bersangkutan akrab dengan media sosial dan mampu mengkomunikasikan segala kegiatannya sebagai birokrat melalui media sosial. Karena itu, Ridwan Kamil dinilai sebagai pemimpin kekinian yang dekat dengan kaum muda.

Pikiran Rakyat sebagai media massa terlihat lebih tajam dalam mengkritisi polemik 
rencana pembangunan Taman Dilan ini sehingga yang awalnya akan dibangun taman akhirnya menjadi Sudut Dilan, yakni sebuah pojok yang ada di taman dekat Gelora Saparua Bandung. Beberapa berita " $P R$ ” bersumberkan para narasumber kritis termasuk para pakar politik serta sejumlah budayawan.

Tribun Jabar, kelihatan sangat berhati-hati dalam memberitakan kasus ini. Di satu pihak dia ingin tidak kehilangan pembacanya di lain pihak, Tribun juga harus melaksanakan fungsi kontrolnya sebagai media massa. Fungsi hiburan media massa diyakini mampu menyedot daya tarik pembaca khususnya kaum milenial. Karena itulah frekuensi pemberitaan tentang film Dilan 1991 lumayan tinggi di Tribun Jabar. Dari 31 judul berita yang berkaitan dengan film Dilan, hanya ada 4 berita yang nadanya mengkritik rencana pembangunan Taman Dilan tersebut. Satu diantaranya dari pengamat ekonomi yang juga mantan Menteri Tenaga Kerja Rizal Ramli. Sikap Tribun Jabar sendiri jika melihat dari editorial yang diturunkannya, di ujung tulisan editorial tersebut berharap agar taman yang akan dibangun menggunakan nama yang lain tidak menggunakan nama Dilan.

Editorial sebagai sikap dari sebuah media bisa dijadikan arah media dalam menilai sebuah peristiwa yang terjadi. Tribun Jabar menuliskan keberhasilan Ridwan Kamil sejak menjadi walikota Bandung yang sangat serius menggarap obyek-obyek wisata di tengah kota sehingga dibangunlah sejumlah taman yang ternyata memiliki daya tarik bagi wisatawan. Salah satunya adalah Taman Alun Alun Bandung sebagai taman besar pertama yang menggunakan rumput sintetis sehingga selalu kelihatan selalu hijau. Alun-alun Bandung ini pun menjadi salah satu destinasi wisata untuk swafoto. Karena keberhasilan pembangunan taman Alun Alun ini ketika Ridwan Kamil menjadi Gubernur Jabar juga dicanangkan pembangunan sejumlah alun-alun yang indah termasuk diantaranya Alun Alun Kabupaten Cianjur oleh Pemerintah Provinsi Jawa Barat (Pemprov Jabar). Berikut ini adalah kutipan dari editorial tersebut:

Memenuhi janji kampanyenya, Ridwan Kamil pun mulai menata alun-alun lainnya yang ada di Jabar. Salah satunya, yang belum lama ini viral, adalah Alun-alun Cianjur. Di tangan Ridwan Kamil, Alun-alun Cianjur menjadi luarbiasa indah dan menjadi kebahagiaan baru yang mungkin juga tak pernah dibayangkan sebelumnya akan terwujud.

Tak hanya Cianjur, alun-alun lain pun mulai ditata. Dananya tentu tak kecil, belasan bahkan puluhan miliar untuk setiap alun-alun. Untuk alun-alun Kabupaten Bandung, misalnya, digelontorkan dana $\mathrm{Rp} 15$ miliar, alun-alun Indramayu Rp 15 miliar, Karawang $\mathrm{Rp} 18$ miliar, Majalengka Rp 18 miliar, Kabupaten 
Tasikmalaya Rp 15 miliar, Sumedang Rp 18 miliar, Kota Sukabumi Rp 18 miliar, atau Kota Cirebon Rp 30 miliar. (“Editorial Tribun Jabar: Taman Dilan,” 2019).

Bagi Tribun Jabar, rencana pembangunan Taman Dilan ini sebetulnya untuk tujuan pembangunan pariwisata di Jawa Barat dan kota Bandung pada khususnya. Namun Pikiran Rakyat mencurigai ada agenda politik lain dari Gubernur Jawa Barat ini untuk kepentingan politik tertentu. Hal ini membuktikan bahwa sebuah berita tidaklah otomatis sebuah realitas, namun sebuah konstruksi realitas yang diproduksi oleh wartawan. Oleh karena itu, sebuah realitas berpotensi dikonstruksi berlainan oleh setiap orang. Wartawan bisa saja memiliki perspektif dan pemaknaan yang berbeda ketika menilai sebuah realitas, dan dapat dipandang dari proses konstruksi realitas mereka yang berwujud teks berita. Berita dalam perspektif konstruksi sosial bukan merupakan realitas atau fakta yang sesungguhnya, namun merupakan produk interaksi antara fakta dan wartawan (Setiowati \& Suciati, 2019).

Film dan Pariwisata seringkali berkorelasi. Contohnya, ketika film Laskar Pelangi yang mengambil lokasi syuting di Provinsi Bangka Belitung pada tahun tahun 2007, dan film tersebut menjadi film favorit pada tahun 2008, maka lokasi syuting film tersebut menjadi amat sangat terkenal sehingga hingga kini menjadi tujuan wisata andalan daerah tersebut. Ruangan kelas serta seluk-beluk lainnya dan terutama bebatuan di sekitar pantai yang jadi lokasi syuting menjadi daya tarik banyak wisatawan untuk datang ke daerah ini. Hal ini dikarenakan film adalah salah satu media komunikasi massa yang secara tradisional menggambarkan kondisi realita sosial (Kristiyono \& Sirikit, 2019), sehingga dapat dijadikan media promosi pariwisata juga.

\section{SIMPULAN}

Pikiran Rakyat mendefinisikan masalah ini sebagai sebuah "agenda seorang politikus lima tahun ke depan”. Pembangunan monumen berupa taman diperkirakan supaya terus diingat oleh generasi milenial untuk tujuan politik tertentu. Sedangkan Tribun Jabar mendefinisikan masalah pembangunan "Sudut Dilan” ini sebagai masalah Pariwisata. Sebagai film yang ditonton (di bioskop) oleh sekitar 6 juta orang ini diharapkan "Sudut Dilan" bakal mampu menyedot para wisatawan yang menonton film itu untuk datang ke Bandung. Namun, penamaannya yang kurang tepat karena sosok Dilan sendiri bukan sosok siswa yang patut diteladani.

Penyebab dari polemik yang muncul, menurut Pikiran Rakyat disebabkan oleh tidak adanya kejelasan urgensi yang logis mengapa 
taman atau sudut di Lapangan Saparua itu harus dibangun dan dinamai Sudut Dilan, sementara sosok Dilan sendiri dalam kisah film itu bukan merupakansosokyangpatutditeladani. "PR"pun lewat pernyataan salah seorang narasumbernya polemik ini merupakan strategi pemasaran dari produk film. Hal yang sama ditulis oleh Tribun Jabar ingin menekankan, bahwa akar masalah dari polemik dan kritik tajam yang muncul tersebut karena sosok Dilan tokoh utama dalam film tersebut merupakan seorang siswa SMA yang tidak memiliki karakter positif. Dilan yang anggota geng motor, tukang berkelahi, bahkan pada cerutrera film tersebut ada penggambaran Dilan menghajar gurunya di sekolah.

Berkaitan dengan literasi, menurut Pikiran Rakyat akan lebih elok jika taman tersebut dinamai Taman Literasi. Lebih baik lagi jika penamaannya mengambil nama tokoh film di Jawa Barat. Kalau pun mau memberikan penghargaan kepada Pidi Baiq yang berhasil membuat sebuah karya sastra yang filmnya ditonton oleh jutaan orang, berikan saja penghargaan langsung kepada penulisnya. Bahkan lebih cocok apabila Taman Literasi itu diberi nama Kang Ibing, Kabayan atau Nyi Iteung yang identik dengan Jawa Barat. Sementara menurut Tribun Jabar, salah satu pertimbangan moral pembangunan Sudut Dilan ini selain untuk meningkatkan kepariwisataan kota Bandung juga taman ini bisa berfungsi sebagai pojok literasi.

Untuk penyelesaian masalah, karena warga Jawa Barat pada umumnya menolak nama Dilan, maka menurut Pikiran Rakyat gagasan Gubernur Jawa Barat yang akan membangun Taman atau Sudut Dilan itu sebaiknya dibatalkan, atau mengganti nama dengan namanama tokoh Jawa Barat. Hal senada dipaparkan Tribun Jabar, bahkan lebih baik dana untuk membangun taman tersebut dialihkan untuk pembangunan yang lebih bermanfaat bagi rakyat misalnya lebih bermanfaat fly-over ke arah Jatinangor yang setiap hari dilanda kemacetan.

\section{DAFTAR PUSTAKA}

Banyak yang Menolak Taman Dilan, Mahasiswi Ini Sebut Lebih Baik Bangun Fly Over ke Jatinangor. (2019, February 14). Tribun Jabar.

Bawazier, S., \& Nurhajati, L. (2018). The media framing of the selfie between Miss Israel and Miss Lebanon from $\mathrm{CNN} \& \mathrm{BBC}$ towards the politic interest. Informasi, 48(2), 195-211. https://doi.org/10.21831/ informasi.v48i2.21205

Dilan dan Milea Kejutkan Warga di Taman Saparua, Sudut Dilan Diresmikan, Jadi Ruang Literasi. (2019, February 27). Tribun Jabar.

Editorial Tribun Jabar: Taman Dilan. (2019, February 23). Tribun Jabar.

Eriyanto. (2002). Analisis framing: konstruksi, ideologi, dan politik media. Yogyakarta: LKiS Yogyakarta.

Film Indonesia. (n.d.). Retrieved November 2, 
2019, from http://filmindonesia.or.id/

Gubernur Jawa Barat, Ridwan Kamil Meresmikan Langsung Sudut Film Dilan yang Berada di Kawasan GOR Saparua, Bandung. (2019, February 24). Tribun Jabar.

Ini Lokasi untuk “Taman Dilan” yang Dibangun Ridwan Kamil, Akan Diisi Mural dan Katakata Puitis. (2019, February 11). Tribun Jabar.

Jemison, M. (2017). Communication considerations for one health: the influence of media framing on representations of a human-bat disease conflict in the Australian print media. Australian Zoologist, 38(4), 505-517. Retrieved from http://10.0.30.202/AZ.2017.002

Kristiyono, J., \& Sirikit, H. (2019). Menelisik siasat cerita digital reality pada film Ready Player One? BRICOLAGE: Jurnal Magister Ilmu Komunikasi, 5(2), 159-176. https://doi.org/http://dx.doi.org/10.30813/ bricolage.v5i02.1885

Maulana, K. A., \& Fatmawati. (2018). Analisis produksi program berita Indonesia Morning Show di News and Entertainment Television. Profetik, 11(2), 58-73. https:// doi.org/10.14421/pjk.v11i2.1423

Maulany, S. P., \& Abdullah, A. (2019). Pemberitaan film A Man Called Ahok dan film 212 di media online. ProTVF: Jurnal Kajian Televisi Dan Film, 3(2), 155-170. https://doi.org/10.24198/ptvf.v3i2.22940

McDonald, D. A. (2019). Framing the "Arab Spring": hip hop, social media, and the American news media. Journal of Folklore Research, 56(1), 105-130. Retrieved from http://e-resources.perpusnas.go.id:2048/ login?url=http://search.ebscohost.com/ login .asp $x$ ?direct $=$ true $\& d b=1$ fh $\& A N=134$ 908144\&site $=$ eds-live
McLennan, C. J., Becken, S., \& Moyle, B. D. (2017). Framing in a contested space: media reporting on tourism and mining in Australia. Current Issues in Tourism, 20(9), 960-980. Retrieved from http://10.0.4.56/1 3683500.2014 .946893

Membincangkan Inggit dan Sudut Dilan. (2019). Pikiran Rakyat.

Nama Dilan di Ruang Publik Berlebihan? Ini Kata Para Pengamat. (2019). Pikiran Rakyat.

Nugroho, C. (2019). Relasi kuasa media dan isu gender dalam program televisi di Indonesia. ProTVF: Jurnal Kajian Televisi Dan Film, 2(2), 111-126. https://doi.org/10.24198/ ptvf.v2i2.20816

Permana, R. S. M., Puspitasari, L., \& Indriani, S. S. (2019). Strategi promosi pada tahapan pra-produksi film "Haji Asrama" (HAS). ProTVF: Jurnal Kajian Televisi Dan Film, 2(2), 145-156. https://doi.org/10.24198/ ptvf.v2i2.20818

Pojok Dilan atau Kabayan dan Nyi Iteung? (2019, March 5). Pikiran Rakyat.

Rawan, B., Hussain, S., \& Khurshid, A. (2018). Media framing and foreign policy: A case study of the coverage of Sino-Pak relations in global media. Dialogue (Pakistan), 13(3), 285. Retrieved from http://e-resources. perpusnas.go.id:2048/login?url=http:// search.ebscohost.com/login.aspx ?direct $=\mathrm{t}$ rue $\& \mathrm{db}=$ tsh $\& \mathrm{AN}=132656514 \&$ site $=$ eds live

Ridwan Kamil Meradang Ditanya Urgensi Bangun Sudut Dilan. (2019, February 26). Pikiran Rakyat.

Sadono, T. P. (2015). Pengaruh menonton film $5 \mathrm{~cm}$ dan tingkat keakraban terhadap sikap nasionalisme mahasiswa Universitas Bunda Mulia. BRICOLAGE: Jurnal Magister Ilmu Komunikasi, 1(1). 
Setiawan, H. (2019). No Title. Bandung: Pikiran Rakyat.

Setiowati, E., \& Suciati, P. (2019). Konstruksi tokoh dalam pemberitaan di media online (analisis framing pemberitaan mundurnya Ahok dari Partai Gerindra di media online). Jurnal Vokasi Indonesia, 7(1), 28-38. https://doi.org/10.7454/jvi.v7i1.141

Shoemaker, P., \& Reese, S. (1996). Mediating the Message: Theories of Influences on
Mass Media Content (2nd ed.). New York: Longman.

Soal Rencana Ridwan Kamil Bikin Taman Dilan, Warga Ini Soroti Beberapa Karakter Negatif Dilan. (2019, February 15). Tribun Jabar.

Sudut Dilan Tak Ada Urgensinya, Hanya Strategi Pemasaran Produk. (2019, February 27). Pikiran Rakyat. 